catarrh in young persons, with hyperæsthesia of the mucous membrane, and chronic catarrhal pneumonia, when limited to the apices of the lungs. In such cases the stimulus and incentive to increased bodily exercise which the air of the Engadine produces, and the activity of the respiratory and circulatory functions which is there aroused, tend to set up a more healthy nutritive action in the pulmonary mucous membrane.

The class of cases in which the climate of the Engadine has appeared to me to be of most use have been those of profound anæmia, associated with nervous exhaustion.and irritability - those cases of so-called cerebral anæmia, which are frequently the result of excess of brain-work, intellectual or emotional. The benefit in such cases is often not at once apparent, and is occasionally experienced more after leaving St. Moritz than while staying there. The attacks of giddiness which such patients suffer from are of ten aggravated on their first arrival in the Engadine. It is common to find these, and others also, complain of uncomfortable feelings in the head, fulness, dizziness, and sometimes a condition bordering on delirium. In cases of anæmia, these symptoms pass away after a few days, but in cases of gout, of chronic rheumatism, and of hepatic disorders, the uncomfortable sensations in the head continue, and they of ten produce considerable alarm by coming on in the night; such patients had better at once take the hint that nature gives them, and remove to a less elevated and a warmer region.

Cases of over-gensitiveness of the skin, giving rise to the tendency to "catch cold" easily, are usually much benefited by a season at St. Moritz.

With regard to St. Moritz itself, one is compelled to admit that places, like men, are rarely improved by popularity. Those who knew St. Moritz five years ago will feel something like sadness when they revisit it now. They will miss its simplicity of manners, its primitive accommodation, its cheapness, and its comparative seclusion. They will find a number of new flaunting villas and modern hotels surrounding the old village; they will find the natives avaricious, and their charges exorbitant, though the accommodation is somewhat improved; and they will find themselves in the midst of a heterogeneous crowd gathered from every quarter of the globe, but chiefly proceeding from those large towns of southern Europe when they become (literally) too. hot for their inbabitants. If you have, during the months of winter in Rome, Naples, Florence, or Nice, been amused by the companionship or bored by the intrusiveness of some new acquaintance, you will find him at St. Moritz in July and August ready to amuse or bore you again.

There is one place, however-quite as conveniently near the baths as the village of St. Moritz itself,-where much of what is objectionable in St. Moritz may be avoided. I mean the hamlet of Campfer. There is an excellent hotel in the place-the Julier-Hof, kept by M. Muller. It is only due to M. Muller to say that he spares no pains to make his hotel as comfortable and as quiet and select as any English family could wish. The food and the cooking are uniformly good. The accommodation at his disposal is, of course, limited, and early application is necessary in order to secure rooms during the months of July and August.

Finally, I would have it constantly borne in mind that there is great variableness in the seasons in the Upper Engadine. The climate of St. Moritz in August, 1869, was very different from the climate of St. Moritz in August, 1870; while the season of 1871 was still more unlike the season of 1872. In August, 1871, there were as many as twenty-one fine days; and out of the nine days on which rain fell five were merely cloudy and showery. There was no severe cold and no snow, and many of the fine days were really warm summer days. In August, 1872, after some very hot days towards the end of July, the weather became very cold, and on the 3rd August the whole valley was covered with snow. Snow fell frequently during the month. There were thirteen fine days, most of which were cold; and eighteen days on which rain or snow fell, and most of these were very cold. Many persons who bore the season of 1871 well and left greatly benefited, suffered much in the season of 1872, and looked forward anxiously to their removal; while many cases of severe forms of illness occurred which were unknown during the milder season.
I must reserve some observations on other health-resorts in the neighbourhood of the Engadine for another communication.

St. James's-street, w.

\section{BIBLICAL OBSTETRICS.}

\author{
BY EDWARD ELLIS, M.D.,
}

PHYSICIAT TO THE VICTORIA HOSPITAL FOR CHILDRJN, LATE PHYSICIAT TO THE SAMARITAN HOSPITAL FOR WOMEN AND CHILDREN.

REFERENCES to matters of science or of natural history are in Holy Writ rather parenthetic or illustrative than direct; customs are described here and there as the historian would describe them, but al ways with a specific moral purpose; and when allusion is made to scientific matters, it is in brief terms and popular language. But scattered up and down the pages of the Old Testament will be found a good number of references to the midwifery and gynæcological knowledge of the Hebrews, not, I think, without interest, and which $I$ have endeavoured to bring together in the following paper.

The first mention of a midwife occurs in Genesis $x \times x v ., 17$; not a very encouraging mention this, however. It was Rachel's second labour, and the midwife lost her patient. A little further on, in the first chapter of Exodus, we have something far more remarkable. In the first place, it seems there were but two midwives for the whole Israelitish community, and their names are given as Shiprah and Puah; honourable women they were, disregarding the cruel edict of the tyrant Pharaoh to slay the men-children, and with the ready wit of their sex defending themselves when interrogated by the king why they had spared the male infants, by saying " that the Hebrew women were not as the Egyptian women, for they are lively and are delivered ere the midwives come in unto them."

Four cases of labour only are alluded to; curiously enough, the first and third were twin cases, the second and fourth fatal ones. They are the cases of Rebekah, of Rachel, of Tamar, and of the wife of Phinehas. It is recorded of the case of Rebekah's twins, that the last took hold of the beel of the first-probably a very rapid delivery. Rachel's was a case of "hard labour," specially so called, proving that at this early period of the world's history, modern accoucheuring difficulties were not unknown. In all likelihood this was a "breech" case, or the midwife could scarcely have said, "Fear not, thou shalt have this son also." The case of Tamar was twins, the child whose band first protruded afterwards receding, his brother coming down and being born first. The case of the wife of Phinehas was especially a sad one: the news that the "ark of God was taken," her father-in-law and her husband both dead, brought on her labour somewhat prematurely, and she died. In her case also the woman tried to comfort her by saying, "Fear not, thou hast borne a son," but she did not regard it, except to name the little one "Ichabod"-the glory is departed from Iarael. This might have been a case of uncontrollable hæmorrhage from shock.

No case is recorded of a stillborn child, but such cases evidently occurred, for Aaron, when he saw Miriam's leprosy said, "Let her not be as one dead, of whom the flesh is half consumed when he cometh out of his mother's womb." This might perhaps be taken to refer to a monstrous birth also; but the reference in 2 Esdras v. 8 is remarkable, "Menstruous women shall bring forth monsters." So no direct case of miscarriage is recorded, but the fact is three times used metaphorically; in Job iii. 16," As an untimely birth I had not been"; in Eccles. vi. 3, "An untimely birth is better than he"; and in Psalm lviii. 8. "Jub" is believed by many to be the most ancient of the sacred writings; miscarriages were, therefore, evidently of occurrence from the very earliest time. And overlaying is at least as old as the time of Solomon, where the child of one of the harlots (to whom he delivered his memorable judgment) " died in the night because she overlaid it." In the case of these two women it would appear that no midwife was present, or any person to assist them. Suckling is alluded to four times-once in this very place, the woman rising up on the third day to give her child suck. Again, Hannah 
would not go to the Temple till she had weaned Samuel. In Maccabees ii. 7-27, a woman says, " $O$ my son, have pity upon me that bare thee nine months in my womb, and gave thee suck three years, and nourished thee," \&c. Scripture does not affirm that suckling commonly prevents conception, but in Hosea i. 8 are these words: "Now, when she (Gomer) had weaned Lo-ruhamah, she conceived, and bare a son."

The references to the menstrual period, the intense defilement it was held to confer upon the woman-e.g., in Lamentations i. 17, "Jerusalem is as a menstruous woman among them"; to barrenness as a mark of disgrace and divine displeasure, and several other similar matters, are also sufficiently curious; but their consideration must be deferred to another opportunity.

Fitzroy-street, Fitzroy-square, W.

\section{NOTES OF A
FATAL CASE OF ACUTE PEMPHIGUS AND GANGRENE, \\ FOLLOWING A MEAL OF PUTRID CONGER EEL.}

\section{By IZETT W. ANDERSON, M.D. EDIN.}

J. D-, a black man, aged thirty, generally enjoyed good health, although a man by no means choice in his food, as he frequently ate garbage of all kinds. On Tuesday evening, the 5th of November, he stewed and ate the head, tail, and liver of a large conger eel (Gymnothorax rostratus of Richard Hill) which, having been killed the previous day, was in a semi-putrid condition. Soon after he was attacked with vomiting, purging, and itching of the skin, which continued until Thursday morning, the 7 th. He then came to me complaining of slight purging, cramps of the legs, and itching of the skin, to relieve which I ordered two grains of calomel and ten grains of Dover's powder. On Saturday, the 9 th, he appeared quite well, and continued so until Thursday, the 14th, when he complained of colic and constipation, for which he had a dose of castor oil. The next day he showed me several large circular and oval white patches on his right buttock, produced by removal of the cuticle. The next day these appeared over the sacrum and the other buttock; and were, I ascertained, caused by large bullæ full of a bloody fluid, which coalescing and rupturing loosened the cuticle, which the patient soon removed in attempting to alleviate the intense itching that existed. The bullæ next appeared on the abdomen, and extended until a circular portion of skin about nine inches in diameter was denuded of cuticle. The front and sides of the lower part of both thighs, the knees, and upper part of the legs were attacked, and the disease extended until the cuticle was removed over a space about ten inches in length. They next appeared on the front of both elbow-joints, and covered a space about ten inches in length by four in breadth. A few isolated ones showed themselves on the front of both legs and feet. The bullæ varied in size, and contained bloody fluid, and on removal of the cuticle the true skin was found covered with a thin, grey, tenacious substance, which was either a superficial slough or a species of diphtheritic exudation. Intolerable itching preceded and accompanied the formation of the bullæ, and the patient was continually scratching the raw surfaces until they bled. The different crops of bullæ did not all come out at the same time, but successively, in the order above-mentioned. During the progress of the eruption, both forearms became considerably swollen, and both hands passed into a state of moist gangrene, all the tissues being white, swollen, emphysematous, and infiltrated with sero-purulent fluid. All the fingers were affected with the dry form of gangrene, and became shrivelled, dry, and horny. Two toes were also attacked with dry gangrene. Soon after the commencement of the eruption the patient's vital powers rapidly declined, until he sank into a typhoid condition, from which he never rallied, and nltimately death took place on the 30 th of November, twenty-five days after eating the putrid conger eel. Treatment was entirely of a stimulating nature, milk, soup, and alcohol being given to a large amount, together with mineral acids, quinine, iron, and occasionally opiates. The raw surfaces were dressed with cotton wadding, and a mixture of olive oil, lime-water, and carbolic acid.

On post-mortem examination the organs were all found healthy except the liver, which was much congested. The lungs were extremely anæmic, being of the same colour as white paper. No secondary purulent deposits were found.

Remarks.-This case is, I think, a rare one, not only from the peculiar symptoms, but also from their chronic nature. Acute cases of fish-poisoning are by no means rare in the West Indies, and they are sometimes fatal. Vomiting, purging, and urticaria, with collapse, of ten follow the use of certain fish, but I have never heard of a case where acute pemphigus and gangrene came on and caused death as long as twenty-five days after eating the fish. I have no intention of entering on the extensive subject of the poisonous fish of the West Indies, but I may remark that some are poisonous only at certain seasons or in certain localities, while others are poisonous at all times and in all places. The conger eel is recognised as one of those that are occasionally poisonous. Old fishermen tell me that, although they often eat the conger eel, they have known persons die after eating it in a perfectly fresh condition. They, however, invariably reject the head and liver, which (with what truth I know not) they consider poisonous, and prepare the fish for cooking by well rubbing it with lime-juice and salt. Little doubt, I think, can exist that all the peculiar symptoms in this case arose from the meal of putrid conger eel. It is, however, difficult to state whether they were caused by the eel containing some poisonous principle in itself, or whether they were due simply to its being in a putrid state, or to both those conditions combined.

Kingston, Jamaica.

\section{g. 算litror}

\section{H O S I TAL PRACTICE,}

\section{BRITISH AND FOREIGN.}

Nulla autem est alia pro certo noscendi via, nisi quamplurimas et morborum et dissectionum historias, tum aliorum, tum proprias collectas habere, et inter se comparare.-MobgaGn De Sed. et Caus. Morb., lib. iv. Procmium.

\section{LONDON HOSPITAL.}

SUDDEN DEATH IN CEREBRAL DISEASE; NECESSITY OF ROUTINE OPHTHALMOSCOPICAL EXAMINATIONS

IN CASES OF DISEASE OF THE BRAIN.

(Under the care of Dr. Huahlings JACKSON.)

IN our "Mirror" of March 29th, 1873, we reported remarks by Dr. Hughlings Jackson on sudden death in several cases of adventitious products of the cerebellum. The following case is another illustration of sudden death, we do not say from cerebral tumour, as no autopsy could be obtained, but in a case of cerebral disease; probably there was a tumour. In cases of vascular tumour of the brain death may occur by hæmorrhage from the growth; but death was too rapid in the case we are about to relate for any variety of intracranial hæmorrhage except that from rupture of an anearism of a large cerebral artery. There was no likelihood of such aneurism in this instance. The case shows also the importance of the routine use of the ophthalmoscope. It might easily have been mistaken for one of hysteria, or, by careless persons, for some affection of the liver. The woman always looked well. But such mistakes could not possibly have been made in this case after the use of the ophtbalmoscope: optic neuritis is always a serious matter. At the very first the patient's husband was told that she was very dangerously ill. As she rapidly improved under large doses of iodide of potassium, it might be supposed that the intracranial disease was syphilitic: this is not really likely. There was certainly nothing characteristic of syphilis about the case. The symptoms were just those which so commonly result from adventitious products of all sorts.

A woman, aged twenty-eight, attended first Oct. 26th, 1872, for severe pain in the head, coming on in paroxysms, and for vomiting. The history she gave was obscure. It seemed probable that about a year before she had had 